\title{
Strengthening Malaysian Parliamentary Democracy Through Private Member's Bills
}

\author{
Nurul Izzah Anwar* and Nurul Jannah Mohd Jailani**
}

\section{Abstract}

At present, the ability of the Malaysian Legislature-specifically the House of Representatives (Dewan Rakyat) - to effectively check and balance the powers of the Executive is impeded by the lack of a formal mechanism enabling the deliberation and debate of Private Member's Bills. The Government or the Executive branch remains the primary agenda-setter in Parliamentary sittings, thus undermining the full extent of legislative independence and representative debate taking place in the August House. Drawing on local and international examples, this article argues in favour of allocating space to Private Member's Bills within the parliamentary agenda and consequently returning legislators their rights and agencies towards strengthening Malaysia's parliamentary democracy.

Keywords: Private Member's Bill, Parliamentary Democracy, Legislative, Executive, Separation of Powers

\section{Introduction}

This article was written mid-pandemic in the middle of an Emergency declared on 12 January 2021. In the same eventful week, Malaysians bid farewell to our most respected and memorable former Lord President of the Supreme Court, Tun Salleh Abbas. These events draw attention to Malaysia's main three branches of parliamentary democracy: the Executive, Judiciary, and the Legislative, all considered the three representatives of the 'government' by the late Tun Salleh Abbas himself. ${ }^{1}$

* YB Nurul Izzah Anwar is Member of Parliament for Permatang Pauh. Email:mp@nurulizzah.com

* Nurul Jannah Mohd Jailani is Research Officer to Member of Parliament for Permatang Pauh.

1 Government of Malaysia v Lim Kit Siang [1988] 2 MLJ 12. 
To quote constitutional expert Shad Saleem Faruqi, the 'three compartments of parliamentary democracy are not supposed to exist in compartmentalised isolation, but [...] act as a check and balance for each other'. ${ }^{2}$ While it is said that the Legislative arm's role is to promulgate, amend, pass and repeal laws, in practice, it is seen to legitimise a set of bills that have been decided upon by the Executive as the latter wields a disproportionate influence over parliamentary affairs. ${ }^{3}$

The limits of legislative action are the subject of this article, specifically with regards to the space accorded for bills brought by private members of Parliament. In this text, we will also highlight the lead author's attempts to push for Private Member's Bills during her tenure as a Member of Parliament from 2008 to the present day as well as comparisons with existing practices in other Commonwealth parliamentary democracies.

\section{Parliamentary agenda}

The Malaysian system is characterised as a parliamentary democracy featuring a constitutional monarchy. ${ }^{4}$ Within it, the Executive is helmed by the Prime Minister, whose domain of power resides with the governing of the nation. As for the Judiciary, other than administering justice according to law, the courts are expected to guard against excesses of the administration and unconstitutional action. The final and third branch, the Legislature - a bicameral parliament consisting of the lower house, the House of Representatives (Dewan Rakyat) and the upper house, the Senate (Dewan Negara) - is tasked with creating and amending laws. The separation of powers within the Malaysian state apparatus is often interpreted as each branch not being permitted to interfere in the functioning of the other, a principle fundamental to an effective, functioning parliamentary system. ${ }^{5}$

However, in practice, the Executive remains primarily the agendasetter in Parliament. ${ }^{6}$ The government has the authority to decide which questions are to be orally debated each day of the sitting, alongside

2 See <https://www.thestar.com.my/opinion/columnists/reflecting-on-thelaw/2018/06/21/proposals-for-parliamentary-reforms-post-ge14-the-institutionalefficacy-of-our-elected-legislature> accessed 17 January 2021.

3 A. Lijphart, Thinking about Democracy: Power Sharing and Majority Rule in Theory and Practice (London, Routledge, 2008).

4 A. Ibrahim and A. Joned, The Malaysian Legal System (Kuala Lumpur, Dewan Bahasa dan Pustaka, 1995).

5 P. Mikuli, 'Separation of Powers' <https://oxcon.ouplaw.com/view/10.1093/lawmpeccol/law-mpeccol-e466> accessed 27 January 2021.

6 Lijphart (n 3). 
the order in which bills are to be read and subsequently debated on the floor. What this usually means is that Private Member's Bills are not given the space to be debated over the course of the Parliamentary session. Furthermore, not only do members of the Executive-led cabinet have influence over the passing of legislation, they also decide which Parliamentary Select Committees are permitted to pass. ${ }^{7}$

\section{Private Member's Bills in Malaysia}

\section{The background}

The Malaysian parliamentary system features three types of bills: Public, Private and Hybrid Bills. Public Bills concern matters of public interest - the Budget, for example, falls under this category. Private Bills, on the other hand, deal with issues relating to a particular group; originating from parties outside of Parliament, whether it be private individuals, NGOs or corporate entities. The utilisation of Private Bills in Malaysia is rare and virtually unheard of. Finally, Hybrid Bills relate to issues that involve matters of both public and private interests; for example, those with widespread public ramifications yet jointly cause a specific impact on a particular group of people. ${ }^{8}$

A Private Member's Bill is defined as a bill brought by a private member of Parliament ${ }^{9}$ who is not a member of the Executive while Government Bills originate from the Executive. As a general rule, bills from the latter are almost always debated and eventually passed in Parliament ${ }^{10}$ provided they gain the support of the majority, with the exception of laws that touch on constitutional matters. ${ }^{11}$ While the utilisation of Private Member's Bills is a concept inherited from the Westminster parliamentary system, the way countries approach and feature Private Member's Bills within their respective parliamentary agendas vastly differ ${ }^{12,13}$.

7 See <https://www.freemalaysiatoday.com/category/nation/2019/04/25/parliamentmulling-11-more-select-committees/> accessed 17 January 2021.

8 See $<$ https://www.parlimen.gov.my/glosari1.html?\&lang=en> accessed 18 January 2021.

9 Private member: any Member of Parliament who is not a member of the cabinet (Executive).

10 W.J.T. Jaafar, 'Achieving real and effective parliamentary scrutiny of the executive' (2008) 89(2) PARLIAMENTARIAN 19.

11 Constitutional amendments require two thirds majority to be passed.

12 W. Case, 'Malaysia in 1992: Sharp Politics, Fast Growth, and a New Regional Role' (1993) 33(2) Asian Survey 184.

13 See section below on Private Member's Bills around the world. 
The procedures for the submission of a Private Member's Bill in Malaysia is described in the Standing Orders of the Dewan Rakyat specifically item 49(1). ${ }^{14}$ To be successfully passed, a Private Member's Bill must first be submitted to the Speaker, who then holds discretionary powers over its listing on the Order Paper. The successful inclusion of a fully-fledged bill is subject to its adherence to the Standing Orders and Federal Law as interpreted by the Speaker. ${ }^{15}$ Being listed on the Order Paper, however, is by no means a guarantee of the said bill being prioritised and later allowed for debate on the floor.

Usually, these types of bills are placed at the bottom of the list as Government bills take precedence for debates on any given day. The Private Member's Bills will typically linger on the Order Paper but will only be debated in the rare instances that it gains Executive approval. ${ }^{16}$ For any given bill to be passed (Private Member's Bill or otherwise), it requires a simple majority of votes in the Dewan Rakyat and the Dewan Negara. The bill is then presented to the Agong for his assent under Article 66 of the Federal Constitution. ${ }^{17}$

To our knowledge, there exists no record of a Private Member's Bill on its own successfully passing into law in Malaysia. The success of such a bill hinges greatly on the ability of the sponsor to convince a member of the Executive branch to take it up, thus converting it into a Government Bill. A Minister within the Executive also has the power to move a bill up the Order Paper, so its debate may take precedence over other Government matters of the day. ${ }^{18}$ This privilege is supported by the Parliament Standing Orders 15(2), which states that 'Government business shall be set down in such order as the Government thinks fit and communicate to the Setiausaha'.

A process that relies so heavily on government assent does not bode well for a truly democratic Parliamentary system as this highlights clearly how power is centralised within the Executive. ${ }^{19}$ In a fully functioning

14 See $<$ https://www.parlimen.gov.my/images/webuser/peraturan_mesyuarat/PMDReng.pdf $>$ accessed 17 January 2021.

15 D. Loh and J.A. Surin, Understanding the Dewan Rakyat (Kuala Lumpur, ZI Publications Sdn Bhd, 2011).

16 Refer to Standing Orders of the Dewan Rakyat, SO 49(4), subject to SO 51.

17 C. Das, 'Democracy And The Sultanate System In Malaysia' (2019) 21 Journal of Malaysian and Comparative Law 97.

18 A.F.A. Hamid, 'Shifting Trends of Islamism and Islamist Practices in Malaysia, 1957-2017' (2018) 7(3) Southeast Asian Studies 363.

19 F.M. Arifin and N. Othman, 'The Dynamic of Policymaking Process in Malaysia' (2018) 10(1) International Journal of West Asian Studies 74. 
Parliamentary system, the Legislative arm is tasked with providing the necessary checks and balances to counter Executive powers. ${ }^{20}$ However, without a mechanism for Opposition and Backbencher MPs to moot Private Member's Bills, their legislative power, and by extension the Legislature, is curtailed.

The process of Private Member's Bills being adopted by Ministries and converted into Government Bills is vague and non-transparent. It is uncertain just how many of these Bills have been successfully taken up as there exists no central repository which records them. However, to offer a personal example of the conversion process, the Sexual Harassment Bill mooted in 2018 - built on years of existing work by the Women's Aid Organisation (WAO) and the Joint Action Group for Gender Equality (JAG) - was adopted by the then Minister of Women, Family and Community Development, Datuk Seri Dr Wan Azizah binti Datuk Dr Wan Ismail as a Government Bill. ${ }^{21}$ To date, however, this bill has not been tabled, nor the latest version of it shared with stakeholders by the current Minister, Datuk Seri Rina Mohd Harun.

Another motion most notably discussed in the public domain was the RUU355, a bill to amend the Syariah Courts (Criminal Jurisdiction) Act 1965 pushed by the President of the Islamic Party (PAS) and Marang MP, Datuk Seri Hj Hadi Awang. The Private Member's Bill was eventually prioritised as an agenda by the then Minister in the Prime Minister's Department, Datuk Seri Azalina Othman. ${ }^{22}$ This was done in accordance with Standing Order 14(2), which states that a minister is able to move a motion to proceed before any predetermined business of the day. The RUU355 was supported by the previous Barisan Nasional (BN) government and considered for conversion to a Government Bill; however, this support was later retracted..$^{23}$

In 1966 Tanjong MP Dr Lim Chong Eu managed to get his original Private Member's Bill approved by the Executive (specifically the Deputy Prime Minister) and processed by the Attorney-General's Office. The said

20 V. Vithiatharan and E.T. Gomez, 'Politics, Economic Crises and Corporate Governance Reforms: Regulatory Capture in Malaysia' (2014) 44(4) Journal of Contemporary Asia 599.

21 WAO, WAO Annual Report 2018 (WAO 2019).

22 K.C.C. Kin, 'The Value of Private Member's Bills in Parliament: A Process Comparison between Malaysia and the United Kingdom' (Penang Institute Issues, 2019) <https:// penanginstitute.org/publications/issues/the-value-of-private-members-bills-inparliament-a-process-comparison-between-malaysia-and-the-united-kingdom/>.

23 SUARAM, Malaysia Human Rights Report 2017: Civil and Political Rights (Petaling Jaya, Suara Inisiatif Sdn Bhd, 2018). 
bill was introduced to amend Article 159(3) of the Federal Constitution and was allowed to be read a second time. Notwithstanding initial government support, the bill was eventually voted down. ${ }^{24}$ Another example of a Private Member's Bill which was allowed for debate but failed to secure the necessary votes was Gua Musang MP Tengku Razaleigh's proposed amendment to the Societies Bill to revive the United Malays National Organisation (UMNO) in 1988. ${ }^{25}$

As described above, many obstacles stand in the way of Private Member's Bills (PMBs) being prioritised. As a result, the PMBs that eventually make it to the debating stage are few and far between. However, there are still merits in championing Private Member's Bills as each one acts as a launchpad for discussions around issues brought up through such proposed bills. These bills may raise awareness on niche issues and may even influence the government to incorporate ideas raised into future Executive-led legislation. ${ }^{26}$

It is with the reasons above that the lead author worked on several Private Member's Bills across the span of her tenure as a Member of Parliament (2008 - present). These Private Member's Bills are listed in Table 1 below, with summaries of each bill to follow.

Table 1. Private Member's Bills brought forward by Nurul Izzah Anwar

\begin{tabular}{|c|l|c|}
\hline No & Private Member's Bill & Year \\
\hline 1. & Industry Skills Education And Training Commission Bill 2018 & 2018 \\
\hline 2. & Racial and Religious Hate Crime Bill 2016 & 2016 \\
\hline 3. & National Harmony and Reconciliation Bill 2016 & 2016 \\
\hline 4. & Sedition Act (Repeal) 2013 & 2013 \\
\hline 5. & Petroleum Development Act 1974 (Amendment) 2012 & 2012 \\
\hline 6. & Printing Presses And Publications Act (Repeal) 2012 & 2012 \\
\hline 7. & Revocation of Emergency Bill 2011 & 2011 \\
\hline
\end{tabular}

24 DR Deb 25 October 1966, Vol. III No. 13.

25 DR Deb 6 December 1988, Jil. II Bil. 63.

26 J.C.H. Lee and others, 'Elections, Repertoires of Contention and Habitus in Four Civil Society Engagements in Malaysia's 2008 General Elections' (2010) 9(3) Social Movement Studies 293. 


\section{Industry Skills Education And Training Commission Bill 2018}

The Industry Skills Education and Training Commission Bill 2018 (ISET) was mooted in 2018 to establish a commission to centralise the curriculum, accreditation and regulation of Technical and Vocational Education Training (TVET) across Malaysia. This Commission was tasked with managing the complex governing of TVET by seven ministries and their relevant agencies, all working in their respective silos.

The government, then Pakatan Harapan $(\mathrm{PH})$ and the preceding Barisan Nasional (BN) governing coalition had commissioned at least four studies on the TVET ecosystem in Malaysia. Closed reports by Boston Consulting Group (BCG), PricewaterhouseCoopers (PWC), Global Market Research and Public Opinion (IPSOS), as well as committees comprising local and international experts, shared one key conclusion: there was a need to streamline programmes and empower one single accreditation authority to enable more students to benefit from curriculums matching the needs of industry. The ISET bill's raison d'être was to fulfil this need. However, the bill required the cabinet's buy-in before being prioritised on the parliamentary agenda.

\section{Racial and Religious Hate Crime Bill 2016}

The Racial and Religious Hate Crime Bill 2016 was recommended alongside the National Harmony and Reconciliation Bill as replacements to the contentious Sedition Act. Its main aim was to punish acts of racial and religious hatred in the pursuit of preserving national harmony whilst concurrently protecting the right to freedom of speech, association and expression.

\section{National Harmony and Reconciliation Bill 2016}

As mentioned above, the National Harmony and Reconciliation Bill 2016 was proposed to replace the Sedition Act. Its explicit aim was to prohibit discrimination in Malaysia on any grounds, whether in terms of ethnicity or gender. This bill was also formulated in light of the work by the National Unity Consultative Council (NUCC), which was originally set up in 2013 but eventually dissolved three years later by then Prime Minister Datuk Seri Najib Razak. ${ }^{27}$

27 See <https://www.freemalaysiatoday.com/category/nation/2016/11/03/mujahidrawa-mourns-death-of-nucc/> accessed 31 January 2021. 


\section{Sedition Act (Repeal) 2013}

The 2013 Private Member's Bill repealing the Sedition Act was drafted in collaboration with the Malaysian Centre for Constitutionalism and Human Rights (MCCHR). The intention was to abolish a draconian law notorious for its use in suppressing civil dissent, silencing legitimate opposition, and denying peaceful assembly. Civil organisations have long called for its repeal for the threat it is said to pose on Malaysian democracy and freedom of speech. ${ }^{28}$ Under this Act, individuals declared by the ruling Government as a threat to public security have been arrested, inclusive of but not limited to legislators and leaders from the opposition $^{29,30}$. The enforcement of this law is seen to be arbitrary and much criticised as a government tool to crack down on dissent without according victims justifiable legal recourse. For this reason, the repeal of the Sedition Act was proposed as part of a larger push for government reforms - an initial pledge made by former Prime Minister Datuk Seri Najib Razak before scaling back due to pressure by ultra-conservative forces. $^{31}$

\section{Petroleum Development Act 1974 (Amendment) 2012}

As a resource-rich nation, the amount of petroleum funds extracted from our national petroleum company, Petronas, to finance public spending has long been a matter of contention for stakeholders. In 2011, Petronas paid $55 \%$ of its net profits to the government, in comparison to the global national oil company average of $38 \% .{ }^{32}$ Despite the public outcry, the government has never divulged the specifics of how this money has been spent. This Private Member's Bill was drafted to address ongoing concerns and called for the transparent disclosure of expenditure extracted from Malaysia's finite natural resources.

28 See <https://www.hrw.org/news/2019/07/17/malaysia-end-use-sedition-act> accessed 17 January 2021.

29 See <https://www.ipu.org/sites/default/files/documents/malaysia-e.pdf $>$ accessed 17 January 2021.

30 K. Loganathan and others, 'Fetters on Freedom of Information and Free Speech in Malaysia: A Study of the Licensing and Sedition Law' (2015) 12(2) e-Bangi 297.

31 See <https://www.article19.org/resources/malaysia-pm-najib-razak-must-fulfillpromise-repeal-sedition-act-without-delay/> accessed 31 January 2021.

32 E.T.H. Lee, 'Scope For Improvement: Malaysia's Oil And Gas Sector' (REFSA, 2013) $<$ https://refsa.org/wp-content/uploads/2020/10/pdfslide.net_og-scoping-reportmalaysia-final-20130701-compressed.pdf> accessed 17 January 2021. 
This bill was also championed in relation to the Extractive Industries Transparency Initiative (EITI), which aims to set a global benchmark for the good governance of oil, gas and mineral resources. By 2014, EITI had formally approached Petronas to adopt its transparency standards, emulating 44 (now $55^{33}$ ) countries that willingly disclosed theirgovernment revenues and company payments for independent scrutiny. ${ }^{34}$

\section{Printing Presses And Publications Act (Repeal) 2012}

Ensuring the freedom of the press was one of the key issues that led to the proposal to repeal the Printing Presses And Publications Act (PPPA) - an act which grants the government absolute power to revoke newspaper licenses. The Act has been condemned by civil society organisations for its role in curbing media freedom and stifling public debate. For some time, media outlets were viewed as subservient to the government in power for fear of violating the PPPA. ${ }^{35}$

The bill repealing the PPPA comes in tandem with the proposal to establish an independent media council to govern media companies, eventually creating a more conducive environment for media freedom and bipartisan coverage. The bill also took into consideration Malaysia's existing defamation laws, which remains far more stringent than in the UK or Australia, and deemed as a sufficient bulwark against false publications. ${ }^{36}$

\section{Revocation of Emergency Bill 2011}

Since the 1960s, Malaysia has been under Emergency rule, whereby any decrees issued are not subject to judicial review. A constitutional amendment in 1960 provided that an Emergency remains in place until revoked by Parliament. ${ }^{37}$ Prior to this year, Emergency rule has

33 See <https://eiti.org/> accessed 16 January 2021.

34 See <https://www.thestar.com.my/business/business-news/2014/06/10/eiti-hopefulof-msia-adopting-transparency-standards/?styl> accessed 17 January 2021.

35 J.M. Fernandez, 'Malaysia's Printing Presses and Publications Act: Time to Discard a Draconian Relic of a Bygone Era' in B. Debatin (ed), The Cartoon Debate and the Freedom of the Press: Conflicting Norms and Values in the Global Media Culture (Berlin, Lit Verlag, 2007).

36 L.J. Lumsden, 'How independent? An analysis of GE13 coverage by Malaysia's online news portal coverage' (2013) 29(2) Jurnal Komunikasi: Malaysian Journal of Communication 1.

37 C. Das, 'The Basic Law Approach to Constitutionalism: Malaysia's Experience Fifty Years On' (2007) 15(2) Asia Pacific Law Review 219. 
been invoked on four occasions - in 1964 because of the confrontation with Indonesia, in 1966 and 1977 to address state political problems in Sarawak and Kelantan, and in 1969 following racial riots in Kuala Lumpur. This Private Member's Bill called for these Emergency declarations to be revoked. At the time, there were 82 related ordinances and laws promulgated from the time of the emergency. Intended for a different time, these laws now serve a very different purpose and are deemed as repressing democratic rights as well as the smooth running of Malaysia's parliamentary democracy. The Revocation of Emergency Bill was submitted six months prior to its eventual revocation by the then Prime Minister, Datuk Seri Najib Razak. ${ }^{38}$

\section{Private Member's Bills around the world}

Private Member's Bills are typically a feature of countries that adopt the Westminster system. As a general rule, Government Bills introduced by the Executive take precedence over Private Member's Bills. ${ }^{39}$ The United Kingdom features a mechanism that allows Private Member's Bills to be fairly selected and then debated on the parliament floor. There are three different methods for a Private Member's Bill to successfully reach the debating stage: the ballot, the ten-minute rule, and presentation by MPs. ${ }^{40}$ Private Members' Bills have precedence over government business on thirteen Fridays in each session under Standing Order 14(8). On the first seven Fridays allotted to Private Members' Bills, priority is given to ballot bills. The British Parliament regularly passes Private Member's Bills, ranging from three to 12 bills in total, for every Parliamentary session since the year 2000. Recently passed bills include the Parental Bereavement (Leave and Pay) Act 2018.

New Zealand also prioritises Members' Bills (up to 1995 known as Private Member's Bills) by dedicating every alternate Wednesday in the duration of their Parliamentary sitting to local, private and members' bills. ${ }^{41}$ Starting with the 2020-2023 Parliamentary term, if a given Member's

38 See <https://www.newmandala.org/nurul-izzah-on-the-path-towardsdemocratising-malaysia/> accessed 26 January 2021.

39 A. Lijphart, Patterns of Democracy: Government Forms and Performance in Thirty Six Countries (London, Yale University Press, 1999).

40 See<https://www.parliament.uk/about/how/laws/bills/private-members/> accessed 15 January 2021.

41 See <https://www.parliament.nz/en/pb/bills-and-laws/proposed-members-bills/> accessed 18 January 2021. 
Bill receives support from 61 members, it will be tabled without going through the ballot. On average, five Member's Bills have been passed every Parliamentary term since 1984. Previous Member's Bills that have made the cut include the Compensation for Live Organ Donors Bill in 2016 and the End of Life Choice Act 2019.

Canada saw 63 Private Member's Bills passed in its Parliament under Stephen Harper's tenure as Prime Minister (2006-2015). Changes to the Canadian Parliament's Standing Orders were made following a report by the McGrath Committee, which acknowledged the importance of Private Member's Bills, inclusive of current rules relating to Private Members' Business, the establishment of the order of precedence, and the procedures such bills are debated. ${ }^{42}$

\section{Making the case for Private Member's Bills in Malaysia}

As discussed in this article, the Malaysian Parliament may recognise Private Member's Bills, however, their tabling is very much under the Executive's discretionary powers. The mechanisms employed by other Commonwealth nations to enable the passing of such bills are useful considerations for Malaysia to allocate space for the fair tabling of Private Member's Bills, independent of the Executive.

\section{Allocating a specific slot for the tabling of Private Member's Bills}

Malaysia could dedicate one day every fortnight for Private Member's Bills as practised by countries such as the United Kingdom and New Zealand. While the UK currently allows Private Member's Bills to be discussed on Fridays, which may impact the quorum on days when members of Parliament return to their respective constituencies, ${ }^{43}$ it remains a viable option for Malaysia since our parliamentary sessions end on Thursdays.

\section{Using a ballot system}

In the UK and New Zealand, the ballot system remains the most effective mechanism allowing Private Member's Bills to be successfully

42 R. MacKay, 'Parliamentary Rules Concerning Private Members' Bills' (2018) Canadian Parliamentary Review 22.

43 See <https://www.hansardsociety.org.uk/publications/guides/private-membersbills\#how-many-private-members-bills-become-law-each-parliamentary-session> accessed 21 January 2021. 
debated. ${ }^{44,}{ }^{45}$ Implementing a ballot system would enable Private Member's Bills to be tabled fairly, without Executive interference. It allows all MPs an equal chance of getting their PMBs selected for debate, without the need for Executive lobbying.

\section{Other considerations}

There may also be a need to introduce a mechanism that reducesinstances of 'filibustering', otherwise known as time-wasting tactics by a mere handful of Members of Parliament who go on to speak at length about a particular bill, thus blocking other Private Member's Bills ranked lower on the Order Paper. This was one of the suggestions proposed to improve existing procedures vis-à-vis the tabling of Private Member's Bills in the UK. ${ }^{46}$ Other suggestions include ensuring that the procedures for Private Member's Bills are simplified to enable more MPs to participate successfully in this democratic and legislative right.

\section{Conclusion}

This article has highlighted the importance of revisiting and reforming the way the Malaysian Parliament approaches Private Member's Bills. True separation of powers can only occur when the Legislative arm has the right to introduce and discuss legislation of their own, independent of the prevailing agenda of the government in power. Creating a mechanism for Private Member's Bills to be fairly debated allows for a more measured and balanced power dynamic between the Executive and Legislative wings, thus expanding the democratic space within the parliamentary process. Malaysia thus far has been lagging behind with a system that does not allow for easy implementation of Private Member's Bills which has resulted in virtually none of them being taken up, as evidenced above. The one-sided nature of the legislation process hamstrings a Parliament unable to exercise its true potential. The good news is that provided there is the political will to make these changes from the prevailing government, the potential solutions are numerous.

44 S. Moriue, 'Support for Private Members' Bills in the United Kingdom and Japan' (2020) 41(3) Statute Law Review 304.

45 B.D. Williams and I.H. Indridason, 'Luck of the draw? Private members' bills and the electoral connection' (2018) 6(02) Political Science Research and Methods 211.

46 See <https://www.hansardsociety.org.uk/publications/guides/private-membersbills $>$ accessed 21 January 2021. 
By dedicating a specific day to Private Member's business and utilising a ballot system for the fair selection of Private Member's Bills, Malaysia will join the ranks of countries such as the United Kingdom and New Zealand, which rightly prioritise theinterests of the electorate by allowing a more diverse set of legislative debate and discussion - which may not be prioritised or be in the interest of the existing ruling clique. Ensuring such mechanisms are in place will allow for crucial legislative matters to be discussed thoroughly in Parliament before securing the majority support to pass. At the very least, it will assist in raising awareness on key issues faced by the electorate and the nation.

Aside from the occasional headline, PMBs remain a parliamentary mechanism far removed from the consciousness of the rakyat. The same is true of other ancillary mechanisms, including the work of our various Parliamentary committees. The reality is Parliament reflects a perception of place with plenty of debate but little actual lawmaking. Whether this perception is accurate is separate from the underutilisation of additional mechanisms to supplement and strengthen the lawmaking process. Ultimately, this underscores the importance of strengthening Malaysian legislators' agency and ability to pass laws in ensuring the expansion and efficacy of our parliamentary democracy.

\section{References}

Arifin F.M. and Othman N., 'The Dynamic of Policymaking Process in Malaysia' (2018) 10(1) International Journal of West Asian Studies 74.

Article 19, 'Malaysia: PM Najib Razak must fulfill promise to repeal Sedition Act without delay' (Article 19, 4 November 2014) <https:// www.article19.org/resources/malaysia-pm-najib-razak-must-fulfillpromise-repeal-sedition-act-without-delay/> accessed 31 January 2021.

Case W., 'Malaysia in 1992: Sharp Politics, Fast Growth, and a New Regional Role' (1993) 33(2) Asian Survey 184.

Chow M.D., 'Parliament mulling 11 more select committees' (The Star, 25 April 2019) <https://www.freemalaysiatoday.com/category/ nation/2019/04/25/parliament-mulling-11-more-select-committees/> accessed 17 January 2021.

Das C., 'The Basic Law Approach to Constitutionalism: Malaysia's Experience Fifty Years On’ (2007) 15(2) Asia Pacific Law Review 219. 
'Democracy And The Sultanate System In Malaysia' (2019)21 Journal of Malaysian and Comparative Law 97.

DR Deb 25 October 1966, Vol. III No. 13.

DR Deb 6 December 1988, Jil. II Bil. 63.

Faruqi S.S., 'Proposals for parliamentary reforms' (The Star, 21 Jun 2018) <https://www.thestar.com.my/opinion/columnists/reflectingon-the-law/2018/06/21/proposals-for-parliamentary-reforms-postge14-the-institutional-efficacy-of-our-elected-legislature $>$ accessed 17 January 2021.

Fernandez J.M., 'Malaysia's Printing Presses and Publications Act: Time to Discard a Draconian Relic of a Bygone Era' in Debatin B. (ed), The Cartoon Debate and the Freedom of the Press: Conflicting Norms and Values in the Global Media Culture (Berlin, Lit Verlag, 2007).

Hamid A.F.A., 'Shifting Trends of Islamism and Islamist Practices in Malaysia, 1957-2017’ (2018) 7(3) Southeast Asian Studies 363.

Hansard Society, 'How many Private Members' Bills become law each parliamentary session?' (Hansard Society, 2021) <https://www. hansardsociety.org.uk/publications/guides/private-membersbills\#how-many-private-members-bills-become-law-eachparliamentary-session> accessed 21 January 2021.

'Private Members' Bills' (Hansard Society, 2021) <https://www. hansardsociety.org.uk/publications/guides/private-members-bills> accessed 21 January 2021.

Human Rights Watch, 'Malaysia: End Use of Sedition Act' (Human Rights Watch, 17 July 2019) <https://www.hrw.org/news/2019/07/17/ malaysia-end-use-sedition-act> accessed 17 January 2021.

Ibrahim A. and Joned A., The Malaysian Legal System (1st edn, Kuala Lumpur, Dewan Bahasa dan Pustaka, 1995).

Inter-Parliamentary Union, 'Decision adopted unanimously by the IPU Governing Council at its 203rd session' (Inter-Parliamentary Union, 18 October 2018) <https://www.ipu.org/sites/default/files/documents/ malaysia-e.pdf $>$ accessed 17 January 2021. 
Jaafar W.J.T., 'Achieving real and effective parliamentary scrutiny of the executive' (2008) 89(2) PARLIAMENTARIAN 19.

Kin K.C.C., 'The Value of Private Member's Bills in Parliament: A Process Comparison between Malaysia and the United Kingdom' (Penang Institute Issues, 18 October 2019) <https://penanginstitute. $\mathrm{org} /$ publications/issues/the-value-of-private-members-bills-inparliament-a-process-comparison-between-malaysia-and-the-unitedkingdom/> accessed 18 January 2021.

Lee E.T.H., 'Scope For Improvement: Malaysia's Oil And Gas Sector' (REFSA, July 2013) <https://refsa.org/wp-content/uploads/2020/10/ pdfslide.net_og-scoping-report-malaysia-final-20130701-compressed. pdf $>$ accessed 17 January 2021.

LeeJ.C.H. and others, 'Elections, Repertoires of Contention and Habitus in Four Civil Society Engagements in Malaysia's 2008 General Elections' (2010) 9(3) Social Movement Studies 293.

Lijphart A., Patterns of Democracy: Government Forms and Performance in Thirty Six Countries (1st edn, London, Yale University Press, 1999).

Thinking about Democracy: Power Sharing and Majority Rule in Theory and Practice. (1st edn, London, Routledge, 2008).

Loganathan K. and others, 'Fetters on Freedom of Information and Free Speech in Malaysia: A Study of the Licensing and Sedition Law' (2015) 12(2) e-Bangi 297.

Loh D. and Surin J.A., Understanding the Dewan Rakyat (1st edn, Kuala Lumpur, ZI Publications Sdn Bhd, 2011).

Lopez G., 'Nurul Izzah on the path towards democratising Malaysia' (New Mandala, 26March 2011)<https://www.newmandala.org/nurulizzah-on-the-path-towards-democratising-malaysia/> accessed 26 January 2021.

Lumsden L.J., 'How independent? An analysis of GE13 coverage by Malaysia's online news portal coverage' (2013) 29(2) Jurnal Komunikasi: Malaysian Journal of Communication 1.

MacKay R., 'Parliamentary Rules Concerning Private Members' Bills' (2018) Canadian Parliamentary Review 22. 
Mahalingam E., 'EITI approaches Petronas to adopt transparency standards' (The Star, 10 Jun 2014) <https://www.thestar.com.my/ business/business-news/2014/06/10/eiti-hopeful-of-msia-adoptingtransparency-standards/?styl> accessed 17 January 2021.

Mikuli P., 'Separation of Powers' (Oxford Constitutional Law, March 2018) <https://oxcon.ouplaw.com/view/10.1093/law-mpeccol/lawmpeccol-e466> accessed 27 January 2021.

Moriue S., 'Support for Private Members' Bills in the United Kingdom and Japan' (2020) 41(3) Statute Law Review 304.

New Zealand Government, 'Proposed members' bills' (New Zealand Government, 2021)<https://www.parliament.nz/en/pb/bills-and-laws/ proposed-members-bills/> accessed 18 January 2021.

Parliament of Malaysia, 'Glossary' (The Official Portal of Parliament of Malaysia, 18 January 2021) <https://www.parlimen.gov.my/glosari1. html?\&lang=en> accessed 18 January 2021.

Standing Orders of the Dewan Rakyat (14th edn, Kuala Lumpur, Parliament of Malaysia, 2018).

SUARAM, Malaysia Human Rights Report 2017: Civil and Political Rights (1st edn, Petaling Jaya, Suara Inisiatif Sdn Bhd, 2018)

Sulong Z., 'Mujahid mourns death of NUCC' (Free Malaysia Today, 3 November 2016) <https://www.freemalaysiatoday.com/category/ nation/2016/11/03/mujahid-rawa-mourns-death-of-nucc/> accessed 31 January 2021.

The Extractive Industries Transparency Initiative, 'Our Purpose' (EITI, 2021)<https://eiti.org/> accessed 16 January 2021.

UK Parliament, 'Private Members' bills' (UK Parliament, 2021) <https:// www.parliament.uk/about/how/laws/bills/private-members/> accessed 15 January 2021.

Vithiatharan V. and Gomez E.T., 'Politics, Economic Crises and Corporate Governance Reforms: Regulatory Capture in Malaysia' (2014) 44(4) Journal of Contemporary Asia 599.

Williams B.D. and Indridason I.H., 'Luck of the draw? Private members' bills and the electoral connection' (2018) 6(02) Political Science Research and Methods 211. 
Women's Aid Organisation, 'WAO Annual Report 2018' (Women's Aid

Organisation, 2019)<https://wao.org.my/wp-content/uploads/2019/07/ WAO-Annual-Report-2018.pdf> accessed 18 January 2021. 